\title{
Tumor necrosis factor $\alpha$-induced protein-3 protects zinc transporter 8 against proinflammatory cytokine-induced downregulation
}

\author{
LIQING CHENG $^{1}$, DONGMEI ZHANG ${ }^{2}$ and BING CHEN ${ }^{1}$ \\ Departments of ${ }^{1}$ Endocrinology and Metabolism, and ${ }^{2}$ Dermatology, Southwest Hospital, \\ Third Military Medical University, Chongqing 400038, P.R. China
}

Received February 27, 2015; Accepted April 15, 2016

DOI: 10.3892/etm.2016.3457

\begin{abstract}
Zinc transporter 8 (ZnT8) is exclusively expressed in the pancreatic islet and is essential for insulin crystallization, hexamerization and secretion. Tumor necrosis factor $\alpha$-induced protein-3 (TNFAIP3) is a zinc finger protein that serves a major role in the negative feedback regulation of NF- $\mathrm{kB}$ signaling in response to multiple stimuli, and is a central regulator of immunopathology. Although the role of TNFAIP3 in diabetes has been extensively studied, its effect on ZnT8 has not been fully elucidated. The present study aimed to verify whether proinflammatory cytokines, tumor necrosis factor $\alpha$ (TNF- $\alpha$ ) and interleukin-1 $\beta$ (IL-1 $\beta$ ), are able to affect ZnT8 expression in islet cells. In addition, the study aimed to determine the effect of TNFAIP3 overexpression on cytokine-altered ZnT8 activity, considering its effect on NF- $\mathrm{KB}$ signaling. Cell-based studies using NIT-1 cells overexpressing TNFAIP3 were used to assess the effect of cytokines on ZnT8 and NF- $\mathrm{kB}$ activation, as well as the effect of TNFAIP3 on ZnT8 expression. Western blot analysis and immunofluorescence staining were employed to determine the protein expression and NF- $\mathrm{kB}$ activation, respectively. The results indicated that cytokine stimulation led to TNFAIP3 upregulation, ZnT8 downregulation and NF- $\kappa \mathrm{B}$ activation. Furthermore, TNFAIP3 overexpression protected ZnT8 from cytokine-induced downregulation. In conclusion, the current results suggest that inflammation or
\end{abstract}

Correspondence to: Professor Bing Chen, Department of Endocrinology and Metabolism, Southwest Hospital, Third Military Medical University, 29 Gaotanyan Main Street, Shapingba, Chongqing 400038, P.R. China

E-mail: chenbingtmmu@163.com

Abbreviations: ZnT8, zinc transporter 8; TNFAIP3, tumor necrosis factor $\alpha$-induced protein-3; GAPDH, glyceraldehyde phosphate dehydrogenase; ZIP, Zrt- and Irt-like protein; TNF, tumor necrosis factor; NF- $\kappa \mathrm{B}$, nuclear factor $\kappa \mathrm{B}$; IL-1 $\beta$, interleukin-1 $\beta$; DMEM, Dulbecco's modified Eagle's medium; FBS, fetal bovine serum

Key words: zinc transporter 8 , tumor necrosis factor $\alpha$-induced protein-3, diabetes, nuclear factor- $\kappa \mathrm{B}$
TNFAIP3 dysfunction may be involved in the pathogenesis of diabetes via ZnT8 expression, besides from islet cell apoptosis. In addition, restricting inflammation and enhancing TNFAIP3 expression may exert a positive effect in diabetes prevention, treatment and pancreatic cell transplantation.

\section{Introduction}

Diabetes, a class of metabolic diseases that are prevalent worldwide affecting 422 million people in 2014 according to the World Health Organization (1), is characterized by hyperglycemia and can cause severe damage to different organs, particularly the eyes, kidneys, nerves, heart and blood vessels. According to the American Diabetes Association, the disease can be classified into two main types, including type 1 and type 2 diabetes (2). Type 1 diabetes results from a cell-mediated autoimmune attack on $\beta$ cells, whereas type 2 diabetes is a low-grade, chronic inflammatory disease that shares a common final pathway with type 1 diabetes, in which activation of the nuclear factor $\kappa \mathrm{B}$ $(\mathrm{NF}-\mathrm{\kappa B})$ signaling pathway causes a reduction in pancreatic $\beta$ cells (3-10).

Zinc participates in numerous biological processes, and is essential for the correct processing, storage, secretion, and function of insulin in pancreatic $\beta$ cells (11-13). Zinc flux is controlled by two types of transporters: The zinc transporter (ZnT; also known as SLC30A) family, and the Zrt- and Irt-like protein (ZIP) family. Typically, the $\mathrm{ZnT}$ family regulates $\mathrm{Zn}^{2+}$ efflux out of the cytoplasm, while the ZIP family regulates $\mathrm{Zn}^{2+}$ influx into the cytoplasm. Although $10 \mathrm{ZnTs}$ and 14 ZIPs have been identified in mammals, ZnT8 is exclusively expressed in the pancreatic islet and serves a major role in $\mathrm{Zn}^{2+}$ efflux from cytoplasm to insulin secretory granules, which is indispensable for insulin crystallization and hexamerization (14-16).

Alterations to ZnT8 expression may affect diabetes pathogenesis. For instance, ZnT8 deletion leads to impaired insulin secretion from pancreatic $\beta$ cells $(17,18)$. In addition, the expression of ZnT8 has been demonstrated to be decreased in the $\beta$ cells of diabetic mice (19). A ZnT8 (or SLC30A8) gene polymorphism has been identified, and is associated with type 2 diabetes (20-22). Furthermore, an autoantibody to ZnT8 is widely considered as a biomarker of autoimmune diabetes $(23,24)$. There is also evidence that zinc has an anti-inflammatory effect, 
and that ZnT8 expression can be downregulated by proinflammatory cytokines, which are expressed at high levels in type 2 diabetes (25-27).

Tumor necrosis factor $\alpha$-induced protein-3 (TNFAIP3) is a zinc finger and ubiquitin-editing protein that is able to inhibit or promote the NF- $\mathrm{NB}$ signaling cascade by attaching to the K48-linked or K63-linked polyubiquitin chains, respectively $(28,29)$. Although TNFAIP3 was originally characterized as an inhibitor of tumor necrosis factor (TNF)-induced apoptosis, it is best characterized as an inhibitor of NF- $\kappa$ B activation (30). Notably, a number of studies have shown the association of TNFAIP3 with common inflammatory and immune diseases, including type 1 diabetes (31-36). Thus, it is possible that TNFAIP3 participates in the pathogenesis of type 1 and type 2 diabetes. Indeed, there is certain evidence indicating this role of TNFAIP3, since TNFAIP3 expression has been found to inhibit hallmarks of diabetes in a number of models, including transplanted islets $(37,38)$, endothelial cells exposed to high glucose (39) and streptozotocin-induced diabetes mice (40).

Based on the aforementioned previous findings, we conclude that cytokines may alter insulin secretion through the induction of apoptosis in pancreatic $\beta$ cells and through the inhibition of insulin secretion via alterations to ZnT8 expression. Therefore, the aim of the present study was to assess whether the expression of TNFAIP3 is altered in patients with diabetes. Furthermore, the study investigated whether proinflammatory cytokines are able to alter the expression of ZnT8 in islet cells, and whether the expression of TNFAIP3 can protect against cytokine-induced ZnT8 alterations. The observations of the present study may reveal a novel view on how proinflammatory cytokines inhibit insulin secretion besides apoptosis of $\beta$ cells, and how TNFAIP3 exerts a beneficial effect on insulin secretion besides its anti-apoptosis effect, which will also provide a potential conception in the prevention and therapy of diabetes.

\section{Materials and methods}

NIT-1 cell culture. NIT-1 cells (murine) were purchased from Focusbio (Guangzhou, China) and were cultured in a $5 \% \mathrm{CO}_{2}$ atmosphere at $37^{\circ} \mathrm{C}$ in low-glucose Dulbecco's modified Eagle's medium (DMEM) supplemented with $15 \%$ heat-inactivated fetal bovine serum (FBS), $100 \mathrm{U} / \mathrm{ml}$ penicillin and $100 \mathrm{~g} / \mathrm{ml}$ streptomycin. All the aforementioned reagents mentioned were purchased from GE Healthcare Life Sciences (Shanghai, China).

Cytokine stimulation. For stimulation assays, cells were plated $\left(10^{6}\right.$ cells/well) in 6-well plates (Sigma-Aldrich, St. Louis, MO, USA). After $48 \mathrm{~h}$ of culturing, the culture medium was changed to serum-reduced culture medium (DMEM and 1\% FBS), containing 1\% FBS supplemented with no cytokines (control), with $10 \mathrm{ng} / \mathrm{ml}$ recombinant murine TNF- $\alpha$ or with $5 \mathrm{ng} / \mathrm{ml}$ recombinant murine interleukin-1 $\beta$ (IL-1 $\beta$; ProSpec, Ness Ziona, Israel). The cells were stimulated with cytokines for 6,24 or $48 \mathrm{~h}$, and then collected by centrifugation at $200 \mathrm{x} \mathrm{g}$ for $5 \mathrm{~min}$ at $4^{\circ} \mathrm{C}$ after digestion with pancreatin digestion (Sigma-Aldrich). Each assay was performed in triplicate.

Adenoviral transfection of NIT-1 cells. The adenovirus expressing human TNFAIP3 and enhanced green fluorescent protein (Ad-TNFAIP3-EGFP; cat. no. V494-20), and the control adenovirus expressing EGFP (Ad-EGFP; cat. no. V493-20) were purchased from Wuhan GenSil Biotechnology (Wuhan, China). Adenovirus-mediated gene transfection was performed following the manufacturer's protocol. Briefly, NIT-1 cells were plated in 6 -well plates $\left(10^{6}\right.$ cells/well). At 1 day after cell adhesion, $1 \mathrm{ml}$ DMEM with Ad-EGFP or Ad-TNFAIP3-EGFP virus [multiplicity of infection (MOI), 200] was added to each well, and the cells were infected for $24 \mathrm{~h}$. The MOI was selected based on the lowest toxicity by viral infection. Following infection, the cells were cultured for an additional $24 \mathrm{~h}$ before being used in further experiments. TNFAIP3 and indicator protein EGFP were co-expressed, and the latter was verified using fluorescence microcopy, while transfection was detected by western blot analysis.

Determination of $N F-\kappa B$ activation. $N F-\kappa B$ activity was assessed using an NF- $\kappa \mathrm{B}$ Activation and Nuclear Translocation Assay kit (Beyotime Institute of Biotechnology, Haimen, China) according to the manufacturer's protocol. Briefly, the NF- $\kappa \mathrm{B}$ major subunit, p65, was labeled with $\mathrm{Cy} 3$ and the nucleus was stained with DAPI. After washing and fixing, cytokine-treated NIT-1 cells were incubated with blocking buffer to block non-specific epitopes. Subsequently, cells were incubated with rabbit anti-mouse NF- $\kappa \mathrm{B}$ p65 antibody at $4^{\circ} \mathrm{C}$ overnight, followed by incubation with a Cy3-conjugated secondary antibody for $1 \mathrm{~h}$ at room temperature and DAPI for $5 \mathrm{~min}$ prior to fluorescence microcopy. All the reagents used in this experiment were included in the kit.

Western blot analysis. Expression of proteins in cells was determined by western blot analysis. GAPDH was used as an internal control. Three rabbit anti-mouse/human polyclonal antibodies for GAPDH (cat. no. sc-25778; 1:400 dilution), TNFAIP3 (cat. no. 23456-1-AP; 1:1,000 dilution) and ZnT8 (cat. no. R12-3525; 1:1,000 dilution) were purchased from Santa Cruz Biotechnology, Inc. (Dallas, TX, USA), Proteintech Group Inc. (Wuhan, China) and Assay Biotechnology Company, Inc. (Sunnyvale, CA, USA), respectively. Polyvinylidene difluoride (PVDF) membranes were purchased from EMD Millipore (Billerica, MA, USA). All other reagents were purchased from Beyotime Institute of Biotechnology. Briefly, harvested NIT-1 cells were lysed and extracted by a standard protocol with cell lysis buffer, and the protein levels were quantified using a Enhanced BCA Protein Assay kit. Proteins were separated by $10 \%$ SDS-PAGE and then transferred to PVDF membranes. Subsequent to blocking with QuickBlock blocking buffer for $10 \mathrm{~min}$ at $25^{\circ} \mathrm{C}$ followed by three washes for $10 \mathrm{~min}$ with western wash buffer, the membranes were incubated overnight at $4^{\circ} \mathrm{C}$ with polyclonal rabbit anti-TNFAIP3, anti-ZnT8 or anti-GAPDH antibodies. Subsequent to washing three times for 10 min with western wash buffer, the membranes were incubated with goat anti-rabbit IgG secondary antibodies conjugated to horseradish peroxidase (cat. no. A0208; 1:1,000 dilution), and an enhanced chemiluminescence detection system (BeyoECL Plus; cat. no. P0018; Beyotime Institute of Biotechnology) were used for detection.

Statistical analysis. Data are presented as the raw values or as the mean \pm standard deviation. IBM SPSS software (version 19.0; IBM Corp., Armonk, NY, USA) was used to perform statistical 
A
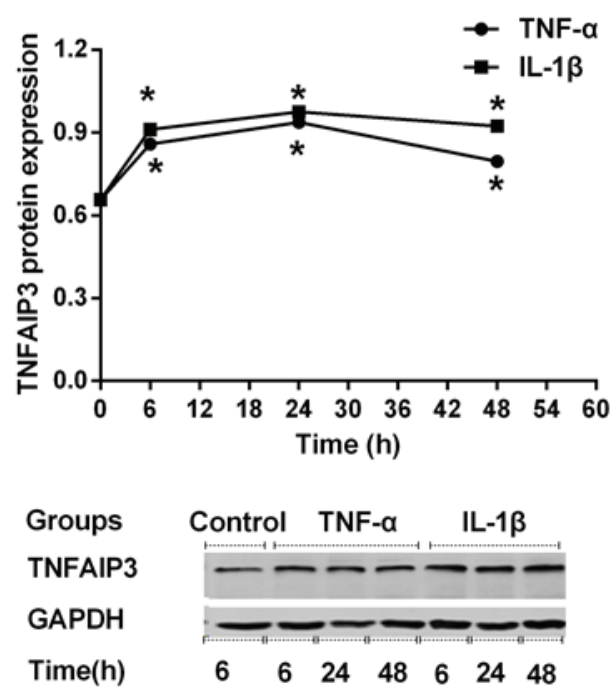

B
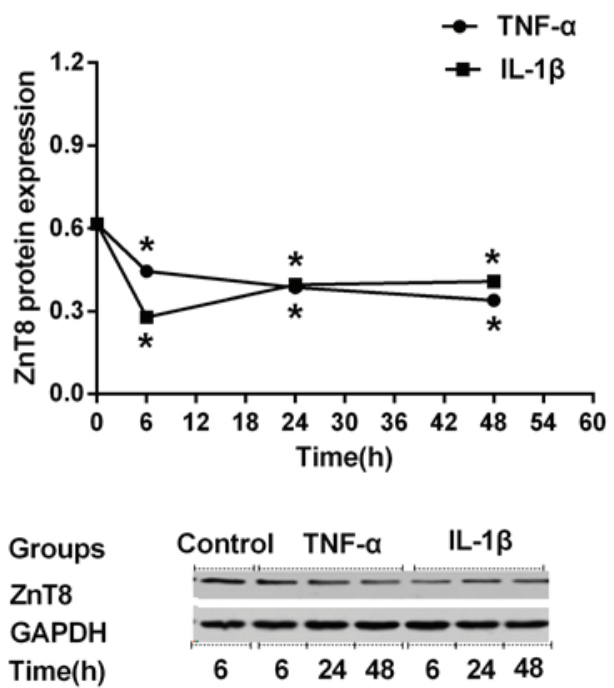

Figure 1. Expression levels of (A) TNFAIP3 and (B) ZnT8 following TNF- $\alpha$ and IL-1 $\beta$ stimulation. NIT-1 cells were treated with no cytokines, with 5 ng/ml murine IL-1 $\beta$ or with $10 \mathrm{ng} / \mathrm{ml}$ murine TNF- $\alpha$ for 6,24 or $48 \mathrm{~h}$. ${ }^{*} \mathrm{P}<0.05$ vs. non-stimulated control TNFAIP3, TNF $\alpha$-induced protein-3; ZnT8, zinc transporter 8 ; TNF, tumor necrosis factor; IL, interleukin.

analyses using one-way analysis of variance, Kruskal-Wallis test or Mann-Whitney U test in order to assess differences, as appropriate. A P-value (two-tailed) of $\leq 0.05$ was considered to indicate a statistically significant difference.

\section{Results}

Cytokine-induced alterations in TNFAIP3 and ZnT8 expression and $N F-\kappa B$ activation. Previous studies have demonstrated the expression of TNFAIP3 $(41,42)$ and ZnT8 $(43,44)$ in several pancreatic $\beta$ cell lines or primary islet cells; however, to date, no such reports concerning their expression in insulin-producing NIT-1 cells exist. Therefore, the present study investigated whether TNFAIP3 and ZnT8 were expressed in NIT-1 cells, and then examined whether their expression was altered by stimulation with TNF- $\alpha$ or IL-1 $\beta$. As shown in Fig. 1, TNFAIP3 (Fig. 1A) and ZnT8 (Fig. 1B) were both expressed in NIT-1 cells, as assessed by western blot analysis. NIT-1 cells demonstrated similar TNFAIP3 expression-time curves $(0,6$, 24 or $48 \mathrm{~h}$ ) when stimulated by TNF- $\alpha$ and IL-1 $\beta$. During the first $6 \mathrm{~h}$ of cytokine stimulation (0-6h), TNFAIP3 expression increased sharply. During the subsequent $18 \mathrm{~h}$ (6-24 h), the upregulation slowed, while TNFAIP3 expression began to slowly decline during the subsequent $24 \mathrm{~h}$ (24-48 h), despite still being higher compared with prior to stimulation (Fig. 1A). Stimulated TNFAIP3 expression levels at all time points (6, 24 and $48 \mathrm{~h}$ ) were significantly altered compared with the control (all $\mathrm{P}<0.001)$. In contrast to TNFAIP3 expression, ZnT8 expression declined rapidly during the first $6 \mathrm{~h}$ of cytokine stimulation. During the subsequent $42 \mathrm{~h}, \mathrm{ZnT} 8$ expression decreased or recovered slowly in the TNF- $\alpha$ or IL- $1 \beta$ groups, respectively (Fig. 1B). In conclusion, stimulated ZnT8 expression levels at all time points $(6,24$ and $48 \mathrm{~h})$ were significantly altered compared with the control (all $\mathrm{P}<0.001$ ).

Furthermore, the present study examined the $N F-\kappa B$ activation in NIT-1 cells subsequent TNF- $\alpha$ and IL-1 $\beta$ stimulation (Fig. 2). In resting cells, NF- $\kappa \mathrm{B}$ is know to be inactivated through it interaction with $\mathrm{I} \kappa \mathrm{B}$. After cells are stimulated, $\mathrm{NF}-\kappa \mathrm{B}$ is released and translocates into the nucleus (45). In order to assess NF- $\kappa \mathrm{B}$ activation, an NF- $\kappa \mathrm{B}$ activation and Nuclear Translocation Assay kit was used in the current study. The cellular p65 subunit of NF- $\mathrm{B}$ was identified using anti-p65 antibodies, which were then labeled by Cy3-coupled secondary antibodies (red fluorescence). Nuclear DNA of the same group was stained with DAPI (blue fluorescence) as an indicator. Merged images demonstrated the positional association between p65 and the nucleus. Compared with the control (Fig. 2A), the TNF- $\alpha$ (Fig. 2B) and IL-1 $\beta$ (Fig. 2C) stimulation resulted in assembly of the p65 subunit in and around the nucleus, which indicated NF- $\kappa \mathrm{B}$ activation.

TNFAIP3 overexpression protects ZnT8 from cytokine-induced downregulation. As previously discussed, stimulation with the TNF- $\alpha$ and IL-1 $\beta$ inflammatory cytokines resulted in $\mathrm{NF}-\kappa \mathrm{B}$ activation and ZnT8 downregulation. It was therefore hypothesized that TNFAIP3, an inhibitor of NF- $\kappa \mathrm{B}$ activation (30), may reverse the low expression of ZnT8 in NIT-1 cells exposed to TNF- $\alpha$ and IL-1 $\beta$. Therefore, the influence of TNFAIP3 overexpression (using a TNFAIP3 overexpressing adenovirus) on the suppression of $\mathrm{ZnT} 8$ expression resulting from cytokine intervention was investigated. As shown in Fig. 3, when stimulated by the same cytokine, the experimental group (transfected with an Ad-TNFAIP3-EGFP adenovirus) presented higher expression of TNFAIP3 compared with the control group (transfected with an Ad-EGFP adenovirus), indicating successful transfection $(\mathrm{P}<0.001$ for TNF- $\alpha$ and IL-1 $\beta$ ). Similarly, the experimental group with high TNFAIP3 expression was shown to express a greater level of ZnT8 when compared with the control group $(\mathrm{P}<0.001$ for TNF- $\alpha$ and IL-1 $\beta$ ). These findings suggest that TNFAIP3 overexpression significantly suppresses cytokine-induced ZnT8 downregulation. 


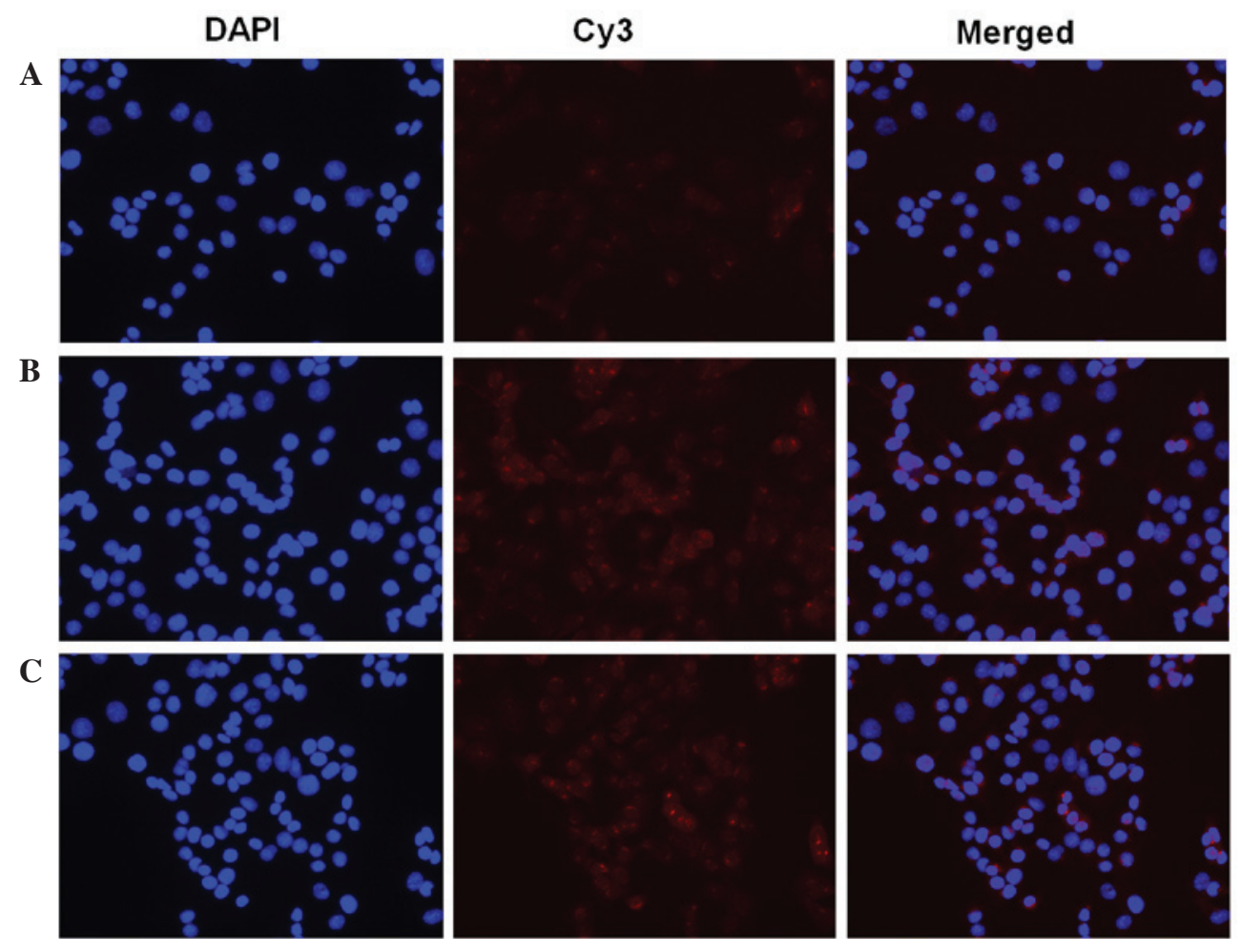

Figure 2. Effects of TNF- $\alpha$ and IL-1 $\beta$ stimulation on NF-кB activation and nuclear translocation. NIT-1 cells were cultured in (A) serum-reduced culture medium containing $1 \%$ fetal bovine serum and Dulbecco's modified Eagle's medium, or exposed to the serum-reduced culture medium supplemented with (B) $10 \mathrm{ng} / \mathrm{ml}$ murine TNF- $\alpha$ for $6 \mathrm{~h}$ or (C) $5 \mathrm{ng} / \mathrm{ml}$ murine IL-1 $\beta$ for $6 \mathrm{~h}$. Cells were labeled with Cy3 (red) and DAPI (blue), and were imaged simultaneously. $\mathrm{TNF}$, tumor necrosis factor; IL, interleukin.

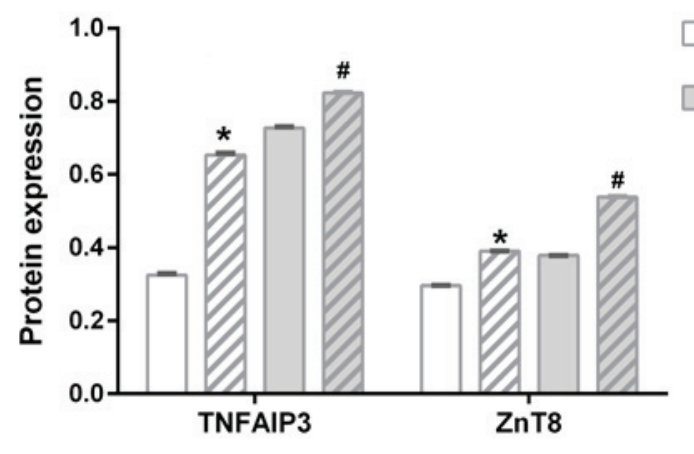

TNF-a/Ad-EGFP WTNF-a/Ad-TNFAIP3-EGFP

IL-1ß/Ad-EGFP $D$ IL-1ß/Ad-TNFAIP3-EGFP

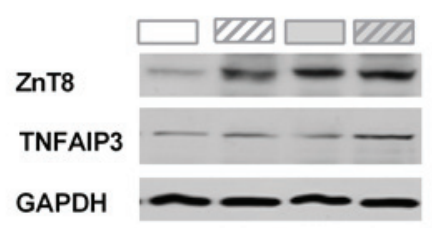

Figure 3. Expression levels of TNFAIP3 and ZnT8 subsequent to TNF- $\alpha$ and IL-1 $\beta$ stimulation in NIT-1 cells that were transfected with Ad-EGFP or Ad-TNFAIP3-EGFP. NIT-1 cells were treated with $5 \mathrm{ng} / \mathrm{ml}$ murine IL-1 $\beta$ or $10 \mathrm{ng} / \mathrm{ml}$ murine TNF- $\alpha$ for $6 \mathrm{~h}$ after transfection. TNF- $\alpha$-stimulated expression: ${ }^{*} \mathrm{P}<0.05$ vs. Ad-EGFP adenovirus transfected control; IL-1 $\beta$-stimulated expression: ${ }^{*} \mathrm{P}<0.05$ vs. Ad-EGFP adenovirus transfected control. TNFAIP3, TNF $\alpha$-induced protein-3; ZnT8, zinc transporter 8; TNF, tumor necrosis factor; IL, interleukin; Ad-EGFP, adenovirus expressing EGFP (control); Ad-TNFAIP3-EGFP, adenovirus expressing TNFAIP3 and EGFP; EGFP, enhanced green fluorescent protein.

\section{Discussion}

The results of the present study, in agreement with the findings of previous studies $(27,46)$, indicated that insulin secretion can be inhibited by proinflammatory cytokines causing dysregulation of $\beta$ cells via ZnT8 downregulation, and a decrease in $\beta$ cell number by affecting apoptosis. The current study showed that proinflammatory cytokines, TNF- $\alpha$ and IL-1 $\beta$, downregulate ZnT8 protein expression in NIT-1 cells. This effect was previously observed in MIN6 cells (27), indicating that decreased ZnT8 expression may contribute to impaired $\beta$ cell function and insulin secretion. ZnT8 is predominantly expressed in pancreatic islets, and is responsible for transporting zinc from the cytoplasm into insulin secretory vesicles, where insulin is stored as a solid hexamer bound with two $\mathrm{Zn}^{2+}$ ions (15). Thus, $\mathrm{Zn}^{2+}$ is essential for the storage, crystallization and secretion of insulin. In addition, a previous study observed that TNF- $\alpha$ and IL-1 $\beta$ were higher in the plasma of diabetes patients (47). It is well established that numerous cytokines, including TNF- $\alpha$, IL-1 $\beta$ and interferon- $\gamma$, contribute to $\beta$ cell dysfunction and death, via activation of the $N F-\kappa B$ signaling pathway (48-50), thus promoting the immune system activity and the transcription of 
proinflammatory and cell survival genes (51). This mechanism has been previously verified using therapeutic drugs (52) and using a mouse allogeneic pancreatic islet graft experiment (53). Furthermore, studies of the human genome have identified numerous genes associated with the pathophysiology of autoimmune and inflammatory diseases, of which numerous are involved in the $\mathrm{NF}-\kappa \mathrm{B}$ signaling pathway $(33,35)$. Therefore, $\mathrm{NF}-\kappa \mathrm{B}$ serves a major role in cytokine-dependent $\beta$ cell dysfunction, and may represent a target for therapeutics to improve islet function during inflammatory insults.

Inappropriate activation of $\mathrm{NF}-\kappa \mathrm{B}$ signaling pathway is a key event in the progressive loss of $\beta$ cells in autoimmune diabetes and type 2 diabetes (54-56). TNFAIP3, an immediate early response gene, serves a critical role in the negative regulation of the NF- $\kappa \mathrm{B}$ signaling pathway, as well as in $\beta$ cell protection, through its actions as a dual ubiquitin-editing protein $(49,57)$. The mechanism through which TNFAIP3 turns off inflammation signaling has previously been described as the disruption of ubiquitin enzyme complexes (58); in cells expressing deficient or mutant TNFAIP3 protein, there is defective removal of Lys63-linked ubiquitin from ubiquitin enzyme complexes following stimulation with TNF (59). Our previous study found that the plasma levels of TNF- $\alpha$ and IL- $1 \beta$ were significantly increased, and TNFAIP3 mRNA and protein expression levels were significant decreased in the peripheral blood mononuclear cells of diabetes patients (60). The decrease in TNFAIP3 mRNA and protein expression levels is consistent with other inflammatory diseases. For instance, TNFAIP3 expression is decreased in systemic lupus erythematosus patients, and the expression level of TNFAIP3 negatively correlates with the systemic lupus erythematosus disease activity index (61).

TNFAIP3 is known for its potent anti-apoptotic activity, particularly in $\beta$ cells. Apoptosis is the main form of $\beta$-cell death in the two forms of diabetes. Previous research suggested that the mechanisms leading to nutrient- and cytokine-induced $\beta$ cell death in type 2 and type 1 diabetes, respectively, share the activation of a final common pathway involving IL-1 $\beta$, $N F-\kappa B$ and Fas (50). TNFAIP3 is one of the anti-apoptotic genes induced by cytokines through $\mathrm{NF}-\kappa \mathrm{B}$ in cultured human islets (62) and INS-1E cells (42); induction of protective genes, such as TNFAIP3, leads to islet survival and function (37). The results of the present study provide a novel role for TNFAIP3 in the protection of normal $\beta$ cell functions via $\mathrm{ZnT}$ 8 downregulation. This was supported by the data obtained through TNFAIP3 overexpression in vitro in islet (NIT-1) cells. Furthermore, inflammatory cytokines were found to downregulate ZnT8 protein expression in NIT-1 cells. Notably, TNFAIP3 overexpression protected against cytokine-induced downregulation of $\mathrm{ZnT}$. This role is in addition to the anti-apoptotic activity of TNFAIP3.

To the best of our knowledge, this is the first study to examine the influence of TNFAIP3 overexpression on cytokine-induced ZnT8 inhibition. One limitation of the current study is that single nucleotide polymorphism of TNFAIP3 was not considered, which may influence its affinity with targets. Future studies will further analyze whether single nucleotide polymorphisms of TNFAIP3 alter the effect of TNFAIP3 on ZnT8 expression, and a gene knockout model will be investigated.

In conclusion, the results of the present study revealed that TNFAIP3 overexpression was able to protect ZnT8 from cytokine-induced downregulation. Thus, it is hypothesized that cytokines may not only lead to the death of $\beta$ cells, but also alter their normal function. Notably, TNFAIP3 serves a positive role through its anti-apoptotic effects and its ability to maintain normal $\beta$ cell function. Therefore, TNFAIP3 may serve a pivotal role in the pathogenesis of diabetes and may offer a novel therapeutic target for the prevention and treatment of diabetes.

\section{Acknowledgements}

The study was partly supported by a grant from the Scientific and Technological Plans of Chongqing (no. cstc2014yykfA 110004). The authors would like to thank all their colleagues for their help in the experiments.

\section{References}

1. Global Report on Diabetes. World Health Organization, Geneva, Swirzerland, 2016.

2. American Diabetes Association: Diagnosis and classification of diabetes mellitus. Diabetes Care 33 (Suppl 1): S62-S69, 2010.

3. Velloso LA, Eizirik DL and Cnop M: Type 2 diabetes mellitus-an autoimmune disease? Nat Rev Endocrinol 9: 750-755, 2013.

4. Itariu BK and Stulnig TM: Autoimmune aspects of type 2 diabetes mellitus - A mini-review. Gerontology 60: 189-196, 2014.

5. Richardson VR, Smith KA and Carter AM: Adipose tissue inflammation: Feeding the development of type 2 diabetes mellitus. Immunobiology 218: 1497-1504, 2013.

6. Akash MS, Rehman K and Chen S: Role of inflammatory mechanisms in pathogenesis of type 2 diabetes mellitus. J Cell Biochem 114: 525-531, 2013.

7. Sell H, Habich C and Eckel J: Adaptive immunity in obesity and insulin resistance. Nat Rev Endocrinol 8: 709-716, 2012.

8. Odegaard JI and Chawla A: Connecting type 1 and type 2 diabetes through innate immunity. Cold Spring Harb Perspect Med 2: a007724, 2012.

9. Guzmán-Flores JM and López-Briones S: Cells of innate and adaptive immunity in type 2 diabetes and obesity. Gac Med Mex 148: 381-389, 2012 (In Spanish).

10. King GL: The role of inflammatory cytokines in diabetes and its complications. J Periodontol 79 (Suppl 8): 1527-1534, 2008.

11. Li YV: Zinc and insulin in pancreatic beta-cells. Endocrine 45: $175-189,2014$

12. Cousins RJ, Liuzzi JP and Lichten LA: Mammalian zinc transport, trafficking and signals. J Biol Chem 281: 24085-24089, 2006.

13. Kambe T, Yamaguchi-Iwai Y, Sasaki R and Nagao M: Overview of mammalian zinc transporters. Cell Mol Life Sci 61: 49-68, 2004.

14. Chimienti F, Devergnas S, Pattou F, Schuit F, Garcia-Cuenca R, Vandewalle B, Kerr-Conte J, Van Lommel L, Grunwald D, Favier A and Seve M: In vivo expression and functional characterization of the zinc transporter ZnT8 in glucose-induced insulin secretion. J Cell Sci 119: 4199-4206, 2006.

15. Chimienti F, Devergnas S, Favier A and Seve M: Identification and cloning of a beta-cell-specific zinc transporter, ZnT-8, localized into insulin secretory granules. Diabetes 53: 2330-2337, 2004.

16. Lemaire K, Ravier MA, Schraenen A, Creemers JW, Van de Plas R, Granvik M, Van Lommel L, Waelkens E, Chimienti F, Rutter GA, et al: Insulin crystallization depends on zinc transporter ZnT8 expression, but is not required for normal glucose homeostasis in mice. Proc Natl Acad Sci USA 106: 14872-14877, 2009.

17. Pound LD, Sarkar SA, Benninger RK, Wang Y, Suwanichkul A, Shadoan MK, Printz RL, Oeser JK, Lee CE, Piston DW, et al: Deletion of the mouse Slc30a8 gene encoding zinc transporter-8 results in impaired insulin secretion. Biochem J 421: 371-376, 2009.

18. Wijesekara N, Dai FF, Hardy AB, Giglou PR, Bhattacharjee A, Koshkin V, Chimienti F, Gaisano HY, Rutter GA and Wheeler MB: Beta cell-specific Znt8 deletion in mice causes marked defects in insulin processing, crystallisation and secretion. Diabetologia 53: 1656-1668, 2010.

19. Tamaki M, Fujitani Y, Uchida T, Hirose T, Kawamori R and Watada H: Downregulation of ZnT8 expression in pancreatic $\beta$-cells of diabetic mice. Islets 1: 124-128, 2009.

20. Jing YL, Sun QM, Bi Y, Shen SM and Zhu DL: SLC30A8 polymorphism and type 2 diabetes risk: Evidence from 27 study groups. Nutr Metab Cardiovasc Dis 21: 398-405, 2011. 
21. Huang Q, Yin JY, Dai XP, Wu J, Chen X, Deng CS, Yu M, Gong ZC, Zhou HH and Liu ZQ: Association analysis of SLC30A8 rs13266634 and rs16889462 polymorphisms with type 2 diabetes mellitus and repaglinide response in Chinese patients. Eur J Clin Pharmacol 66: 1207-1215, 2010.

22. Chen G, Xu Y, Lin Y, Lai X, Yao J, Huang B, Chen Z, Huang H, Fu X, Lin L, et al: Association study of genetic variants of 17 diabetes-related genes/loci and cardiovascular risk and diabetic nephropathy in the Chinese She population. J Diabetes 5: $136-145,2013$.

23. Sørgjerd EP, Skorpen F, Kvaløy K, Midthjell K and Grill V: Prevalence of ZnT8 antibody in relation to phenotype and SLC30A8 polymorphism in adult autoimmune diabetes: Results from the HUNT study, Norway. Autoimmunity 46: 74-79, 2013.

24. Skärstrand H, Lernmark A and Vaziri-Sani F: Antigenicity and epitope specificity of ZnT8 autoantibodies in type 1 diabetes. Scand J Immunol 77: 21-29, 2013.

25. Vasto S, Mocchegiani E, Malavolta M, Cuppari I, Listì F, Nuzzo D, Ditta V, Candore G and Caruso C: Zinc and inflammatory/immune response in aging. Ann N Y Acad Sci 1100: $111-122,2007$

26. Egefjord L, Jensen JL, Bang-Berthelsen CH, Petersen AB, Smidt K, Schmitz O, Karlsen AE, Pociot F, Chimienti F, Rungby J and Magnusson NE: Zinc transporter gene expression is regulated by pro-inflammatory cytokines: A potential role for zinc transporters in beta-cell apoptosis? BMC Endocr Disord 9: 7, 2009

27. El Muayed M, Billings LK, Raja MR, Zhang X, Park PJ, Newman MV, Kaufman DB, O'Halloran TV and Lowe WL Jr: Acute cytokine-mediated downregulation of the zinc transporter ZnT8 alters pancreatic beta-cell function. J Endocrinol 206: $159-169,2010$

28. Chen ZJ: Ubiquitination in signaling to and activation of IKK Immunol Rev 246: 95-106, 2012

29. Pickart CM and Eddins MJ: Ubiquitin: Structures, functions, mechanisms. Biochim Biophys Acta 1695: 55-72, 2004.

30. Vereecke L, Beyaert R and van Loo G: The ubiquitin-editing enzyme A20 (TNFAIP3) is a central regulator of immunopathology. Trends Immunol 30: 383-391, 2009.

31. Hughes LB, Reynolds RJ, Brown EE, Kelley JM, Thomson B Conn DL, Jonas BL, Westfall AO, Padilla MA, Callahan LF, et al: Most common single-nucleotide polymorphisms associated with rheumatoid arthritis in persons of European ancestry confer risk of rheumatoid arthritis in African Americans. Arthritis Rheum 62: 3547-3553, 2010.

32. Tejasvi T, Stuart PE, Chandran V, Voorhees JJ, Gladman DD, Rahman P, Elder JT and Nair RP: TNFAIP3 gene polymorphisms are associated with response to TNF blockade in psoriasis. J Invest Dermatol 132: 593-600, 2012.

33. Fung EY, Smyth DJ, Howson JM, Cooper JD, Walker NM,Stevens H, Wicker LS and Todd JA: Analysis of 17 autoimmune disease-associated variants in type 1 diabetes identifies 6q23/TNFAIP3 as a susceptibility locus. Genes Immun 10: 188-191, 2009.

34. Graham RR, Cotsapas C, Davies L, Hackett R, Lessard CJ, Leon JM, Burtt NP, Guiducci C, Parkin M, Gates C, et al: Genetic variants near TNFAIP3 on 6q23 are associated with systemic lupus erythematosus. Nat Genet 40: 1059-1061, 2008

35. Adrianto I, Wen F, Templeton A, Wiley G, King JB, Lessard CJ, Bates JS, Hu Y, Kelly JA, Kaufman KM, et al: Association of a functional variant downstream of TNFAIP3 with systemic lupus erythematosus. Nat Genet 43: 253-258, 2011.

36. Eyre S, Hinks A, Bowes J, Flynn E, Martin P, Wilson AG, Morgan AW, Emery P, Steer S, Hocking LJ, et al: Overlapping genetic susceptibility variants between three autoimmune disorders: Rheumatoid arthritis, type 1 diabetes and coeliac disease. Arthritis Res Ther 12: R175, 2010.

37. Wang H, Ferran C, Attanasio C, Calise F and Otterbein LE: Induction of protective genes leads to islet survival and function. J Transplant 2011: 141898, 2011

38. Grey ST, Longo C, Shukri T, Patel VI, Csizmadia E, Daniel S, Arvelo MB, Tchipashvili V and Ferran C: Genetic engineering of a suboptimal islet graft with A20 preserves beta cell mass and function. J Immunol 170: 6250-6256, 2003.

39. Hou CL, Zhang W, Wei Y, Mi JH, Li L, Zhou ZH, Zeng W and Ying DJ: Zinc finger protein A20 overexpression inhibits monocyte homing and protects endothelial cells from injury induced by high glucose. Genet Mol Res 10: 1050-1059, 2011.

40. Yu LY, Lin B, Zhang ZL and Guo LH: Direct transfer of A20 gene into pancreas protected mice from streptozotocin-induced diabetes. Acta Pharmacol Sin 25: 721-726, 2004.
41. Tan BM, Zammit NW, Yam AO, Slattery R, Walters SN, Malle E and Grey ST: Baculoviral inhibitors of apoptosis repeat containing (BIRC) proteins fine-tune TNF-induced nuclear factor $\kappa \mathrm{B}$ and c-Jun N-terminal kinase signalling in mouse pancreatic beta cells Diabetologia 56: 520-532, 2013

42. Ortis F, Pirot P, Naamane N, Kreins AY, Rasschaert J, Moore F, Théâtre E, Verhaeghe C, Magnusson NE, Chariot A, et al: Induction of nuclear factor-kappaB and its downstream genes by TNF-alpha and IL-1beta has a pro-apoptotic role in pancreatic beta cells. Diabetologia 51: 1213-1225, 2008.

43. Fu Y, Tian W, Pratt EB, Dirling LB, Shyng SL, Meshul CK and Cohen DM: Down-regulation of ZnT8 expression in INS-1 rat pancreatic beta cells reduces insulin content and glucose-inducible insulin secretion. PLoS One 4: e5679, 2009.

44. Huang L: Zinc and its transporters, pancreatic beta-cells, and insulin metabolism. Vitam Horm 95: 365-390, 2014.

45. Shembade N, Ma A and Harhaj EW: Inhibition of NF-kappaB signaling by $\mathrm{A} 20$ through disruption of ubiquitin enzyme complexes. Science 327: 1135-1139, 2010.

46. Feve B and Bastard JP: The role of interleukins in insulin resistance and type 2 diabetes mellitus. Nat Rev Endocrinol 5: 305-311, 2009.

47. Reinehr T, Karges B, Meissner T, Wiegand S, Stoffel-Wagner B, Holl RW and Woelfle J: Inflammatory markers in obese adolescents with type 2 diabetes and their relationship to hepatokines and adipokines. J Pediatr, S0022-3476(16)00277-8, 2016.

48. Liuwantara D, Elliot M, Smith MW, Yam AO, Walters SN, Marino E, McShea A and Grey ST: Nuclear factor-kappaB regulates beta-cell death: A critical role for A20 in beta-cell protection. Diabetes 55: 2491-2501, 2006

49. Melloul D: Role of NF-kappaB in beta-cell death. Biochem Soc Trans 36: 334-339, 2008.

50. Cnop M, Welsh N, Jonas JC, Jörns A, Lenzen S and Eizirik DL: Mechanisms of pancreatic beta-cell death in type 1 and type 2 diabetes: Many differences, few similarities. Diabetes 54 (Suppl 2): S97-S107, 2005.

51. Baltimore D: NF-kB is 25. Nat Immunol 12: 683-685, 2011.

52. Liu XH, Wang YP, Wang LX, Chen Z, Liu XY and Liu LB: Exendin-4 protects murine MIN6 pancreatic $\beta$-cells from interleukin-1 $\beta$-induced apoptosis via the NF- $\kappa \mathrm{B}$ pathway. J Endocrinol Invest 36: 803-811, 2013.

53. Eldor R, Abel R, Sever D, Sadoun G, Peled A, Sionov R and Melloul D: Inhibition of nuclear factor- $\kappa \mathrm{B}$ activation in pancreatic $\beta$-cells has a protective effect on allogeneic pancreatic islet graft survival. PLoS One 8: e56924, 2013.

54. Donath MY and Shoelson SE: Type 2 diabetes as an inflammatory disease. Nat Rev Immunol 11: 98-107, 2011.

55. Kiechl S, Wittmann J, Giaccari A, Knoflach M, Willeit P, Bozec A, Moschen AR, Muscogiuri G, Sorice GP, Kireva T, et al: Blockade of receptor activator of nuclear factor- $\kappa \mathrm{B}$ (RANKL) signaling improves hepatic insulin resistance and prevents development of diabetes mellitus. Nat Med 19: 358-363, 2013.

56. Kim HS, Han MS, Chung KW, Kim S, Kim E, Kim MJ, Jang E, Lee HA, Youn J, Akira S, Lee MS: Toll-like receptor 2 senses beta-cell death and contributes to the initiation of autoimmune diabetes. Immunity 27: 321-333, 2007.

57. Coornaert B, Carpentier I and Beyaert R: A20: Central gatekeeper in inflammation and immunity. J Biol Chem 284: 8217-8221, 2009.

58. Wertz IE, Newton K, Seshasayee D, Kusam S, Lam C, Zhang J, Popovych N, Helgason E, Schoeffler A, Jeet S, et al: Phosphorylation and linear ubiquitin direct A20 inhibition of inflammation. Nature 528: 370-375, 2015

59. Zhou Q, Wang H, Schwartz DM, Stoffels M, Park YH, Zhang Y, Yang D, Demirkaya E, Takeuchi M, Tsai WL, et al: Loss-of-function mutations in TNFAIP3 leading to A20 haploinsufficiency cause an early-onset autoinflammatory disease. Nat Genet 48: 67-73, 2016.

60. Cheng L, Zhang D, Jiang Y, Deng W, Wu Q, Jiang X and Chen B: Decreased A20 mRNA and protein expression in peripheral blood mononuclear cells in patients with type 2 diabetes and latent autoimmune diabetes in adults. Diabetes Res Clin Pract 106: 611-616, 2014.

61. Li D, Wang L, Fan Y, Song L, Guo C, Zhu F, Zhang L and Shi Y: Down-regulation of A20 mRNA expression in peripheral blood mononuclear cells from patients with systemic lupus erythematosus. J Clin Immunol 32: 1287-1291, 2012.

62. Sarkar SA, Kutlu B, Velmurugan K, Kizaka-Kondoh S, Lee CE, Wong R, Valentine A, Davidson HW, Hutton JC and Pugazhenthi S: Cytokine-mediated induction of anti-apoptotic genes that are linked to nuclear factor kappa-B (NF-kappaB) signalling in human islets and in a mouse beta cell line. Diabetologia 52: 1092-1101, 2009. 